\title{
The implementation of the paediatric footwear program at community health level
}

\author{
Alicia James ${ }^{*}$, Cylie Williams, Christine Pappon \\ From Australasian Podiatry Council Conference 2011 \\ Melbourne, Australia. 26-29 April 2011
}

\section{Background}

Children spend around 30 hours a week in their school shoes - that's in excess of 15,000 hours during their school years. Correctly fitted shoes help reduce the risk of injury, improve comfort and assist in gross motor development and participation. Recent research indicates that foot deformities in children who wear incorrectly fitting footwear are increased, following the closure of a local shoe store and parents relating to podiatry staff of the financial difficulties of providing appropriate footwear, the podiatrist developed a quality project. The aim of the project was to provide cost effective and safe footwear for children that attend the services of Greater Dandenong and Cardinia Casey Community Health.

\section{Methods}

200 local school children were assessed and 80 were determined to be wearing inappropriate fitting footwear. Bata footwear based in Mornington was approached and agreed to support the footwear program in the provision of footwear at a reduced cost for community health clients.

\section{Results/conclusions}

The paediatric footwear program in the first 4 months has fitted over 120 children, with a follow-up qualitative survey to be conducted over the following months. Parents have welcomed this service and have regularly reported learning more about correctly fitting shoes and this service provision a welcome financial relief during hardship.

Published: 20 May 2011

Southern Health Community Services, Australia

doi:10.1186/1757-1146-4-S1-P29

Cite this article as: James et al:: The implementation of the paediatric footwear program at community health level. Journal of Foot and Ankle Research 2011 4(Suppl 1):P29.
Submit your next manuscript to BioMed Central and take full advantage of:

- Convenient online submission

- Thorough peer review

- No space constraints or color figure charges

- Immediate publication on acceptance

- Inclusion in PubMed, CAS, Scopus and Google Scholar

- Research which is freely available for redistribution

\section{() Biomed Central}

\section{Biomed Central}

(c) 2011 James et al; licensee BioMed Central Ltd. This is an open access article distributed under the terms of the Creative Commons Attribution License (http://creativecommons.org/licenses/by/2.0), which permits unrestricted use, distribution, and reproduction in any medium, provided the original work is properly cited. 